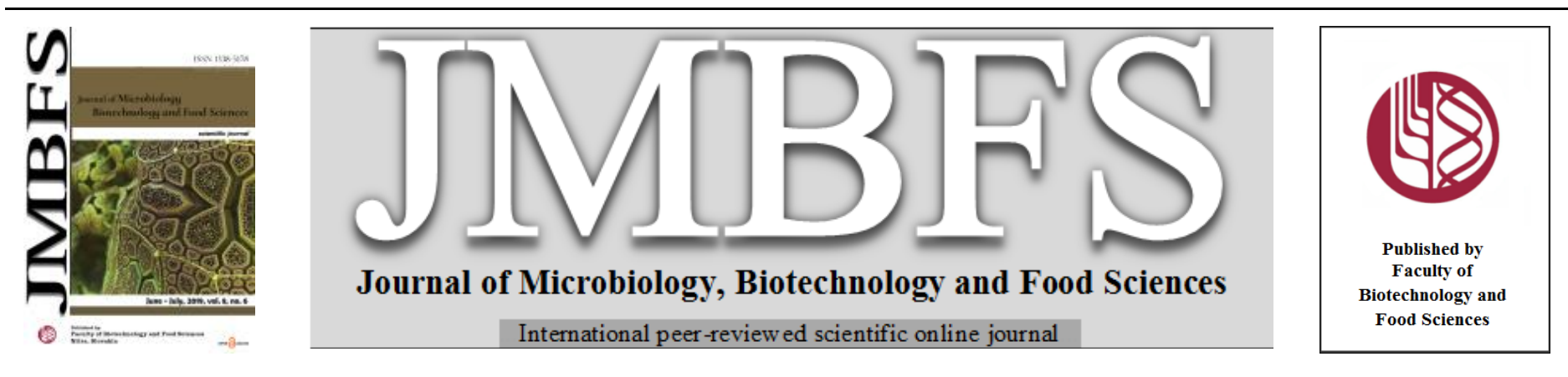

\title{
APPLICATION OF A TWO-STAGE AGITATION SPEED CONTROL STRATEGY TO ENHANCE YELLOW PIGMENTS PRODUCTION BY MONASCUS ANKA MUTANT
}

\author{
Bo Zhou*1,2, Yuan Tian ${ }^{1,2}$, Haiyan Zhong ${ }^{1,2}$ \\ Address(es): DSC, Associate Prof. Bo Zhou, \\ ${ }^{1}$ School of Food Science and Engineering, Central South University of Forestry and Technology, Changsha, 410004, China. Tel:+86-731-85623240; Fax:+86-731- \\ 85623240. \\ ${ }^{2}$ Hunan Key Laboratory of Processed Food for Special Medical Purpose, Changsha, 410004, China. Tel:+86-731-85623240; Fax:+86-731-85623240.
}

*Corresponding author: zhbo78@126.com; zhbofood@cusft.edu.cn

doi: 10.15414/jmbfs.2019.8.6.1260-1264

ARTICLE INFO

Received 8. 3. 2018

Revised 16. 1. 2019

Accepted 29. 1. 2019

Published 1. 6. 2019

Regular article OPEN $\partial_{\text {ACCESS }}$

\begin{abstract}
Monascus anka mutant strain was isolated using conventional mutation techniques in our laboratory. In our previous study, strain Monascus anka mutant showed high yield of yellow pigments with the characteristics of high protein adhesion, thermal stability, and wide-pH stability. This work focused on the agitation optimization in a $5 \mathrm{~L}$ fermentor of strain Monascus anka mutant and two stage agitation speed control strategy was operated as follows: the agitation speed was $400 \mathrm{r} / \mathrm{min}$ to improve the Monascus growth and yellow pigments production before culturing 96 hour and then $300 \mathrm{r} / \mathrm{min}$ was carried out to extend the time of yellow pigment production with efficient using substrate. The yield of monascus yellow pigments reached $149.43 O D$, which was $49.37 \%, 49.25 \%, 35.56 \%, 18.73 \%$, and $41.01 \%$ higher than that of $250 \mathrm{r} / \mathrm{min}, 300 \mathrm{r} / \mathrm{min}, 350 \mathrm{r} / \mathrm{min}, 400 \mathrm{r} / \mathrm{min}$, and $450 \mathrm{r} / \mathrm{min}$ fermentation, respectively. The maximum specific growth rate $\left(\mu_{\max }\right)$ and the maximum specific production rate of yellow pigments $\left(q_{y}\right)$ reached $0.0528 \mathrm{~h}^{-1}$ and $0.2177 O D \cdot \mathrm{g}^{-1} \cdot \mathrm{h}^{-1}$, respectively. Specific growth rate $(\mu)$ maintained higher than $0.01 \mathrm{~h}^{-1}$ from 6 hours to 54 hours, and $q_{y}$ could maintain at $0.10 O D \cdot \mathrm{g}^{-1} \cdot \mathrm{h}^{-1}$ from 24 hour to 66 hour, which could not be obtained by single agitation control. The data of this work could contribute to making the industrial production of Monascus yellow pigments feasible.
\end{abstract}

\section{INTRODUCTION}

Food colorants can be classified into synthetic colorants such as quinoline yellow (Zhang et al., 2015) and tartrazine (Xu et al., 2015), as well as natural ones, such as lycopene (Xu et al., 2016), and curcumin (Upadhyaya, et al., 2015). At present, natural pigments comprise $31 \%$ of the food pigments market (reach up to US $\$ 27.5$ billion in 2018 (Mapari et al., 2010). However, due to a few safety hazards, natural yellow pigments from animals, plants, or microorganisms have become more attractive in recent years (Vendruscolo et al., 2016). Among these pigments, microbiology pigments have a good quality for harvest, scale-up of production is easier and they are not subject to the vagaries of nature (Gomes $\boldsymbol{e t}$ al., 2016). However, prior to food use, toxicological assessments must be conducted because some fungal species producing pigments are also mycotoxigenic producers (Mapari et al., 2009b). Only Monascus is an important microbial resource now in use to produce pigments in an industrial level.

Thousands years ago, ancient Chinese had been using Monascus-fermented red rice as a food colorant to make red rice wine, red soybean cheese, meat and fish products and so on (Blance et al., 1994; Ma et al., 2000; Wild et al., 2002). Currently, more than 50 patents regarding to utilization of Monascus pigments for food have been issued in Japan, the United States, France, and Germany (Lin et al., 1992; Wang et al, 2007). The pigments produced by original Monascus contains three categories of pigments, yellow (monascin and ankaflavin), orange (monascorubrin and rubropunctatin), and red (monascorubramine and rubropunctamine) pigments (Xiong et al., 2015). Among these, the red pigments have been widely used in Asia for centuries as food colorant and now have been successfully produced by fermentation (Feng et al., 2012). Because of their excellent resistance to photodegradation and their $\mathrm{pH}$ and thermal stability (Mapari et al., 2009a), Monascus yellow pigments have been receiving much attention. Except for uses as colorants, Monascus yellow pigments have been reported to possess health benefits, such as in reducing diabetes and obesity (Hsu et al., 2014), hypolipidemic (Lee et al., 2010), anti-obesity (Lee et al., 2013), anti-inflammation (Hsu et al., 2012), antitumor (Su et al., 2005; Lee et al., 2013) and antioxidative stress (Shi et al., 2012), and have wider applications than its in the food industry (Klinsupa et al., 2016). Research continues in the development of improved Monascus yellow pigments yields, as well as in identifying new Monascus yellow pigments (Krairak et al., 2000; Chen et al., 2015). Monascus yellow pigments have been widely researched due to, which are related to the molecular structures of yellow pigments (Su et al., 2005). In the last few decades, 35 Monascus yellow pigments and its derivatives have been identified and characterized (Gong and Zhengqiang, 2016). However, the yellow pigments are still not suitable for industrial production, due to their relatively low production and purity, unavailability of microbial species. Not only microbial genus, but also the environmental conditions play a key influence on monascus yellow pigments production in submerged culture. Environmental conditions include chemical conditions like the type and content of carbon, nitrogen, phosphate, and metals, and physical conditions like mechanical stress, temperature, agitation and $\mathrm{pH}$ (Shi et al., 2015; Bo et al., 2009; Hu et al., 2012; Tao et al., 2017). Meantime, fungal morphology, influenced by genotypes of strains and environmental conditions (Kaup et al., 2008; Krull $\boldsymbol{e t}$ al., 2010), is also considered as a key bioprocess parameter for submerged, which not only has a significant impact on mixing and mass transfer, but also determines the overall process productivities and subsequent economics (Wucherpfennig et al., 2011; Hyun et al., 2002). In our preliminary experiments (Bo et al., 2009; 2012; 2014), the $\mathrm{pH}$, aeration and temperature influenced the Monascus yellow pigments production by Monascus anka mutant in $5 \mathrm{~L}$ fermenter. Therefore, the aim of this work was to systematically investigate the effect of agitation on the production of the yellow pigments in Monascus anka mutant.

\section{MATERIALS AND METHODS}

\section{Organism and cultivation}

Microorganism used in this study is Monascus anka mutant, which was screened from physical and chemical combination mutagenesis in our laboratory (Bo et al., 2009). Stock cultures of the mutant were maintained on wort agar slants, which contains $15^{\circ}$ wort (provided by Guangzhou Zhujiang Beer Co., Ltd, China) and $20 \mathrm{~g} / \mathrm{L}$ agar (Difco Labatory, Loveton Circle, USA), and subcultivated periodically. Cultures were reactivated by being transferred onto fresh wort agar 
slants. After cultivation for $2-3$ days at $31{ }^{\circ} \mathrm{C}$, spores were collected with $5 \mathrm{~mL}$ sterilized water, and the corrected spore suspension was used as inoculum preparation. Spores suspension $(0.3 \mathrm{~mL})$ was inoculated in $250 \mathrm{~mL}$ Erlenmeyer flasks containing $30 \mathrm{~mL}$ of seed culture medium which was composed of $30 \mathrm{~g} / \mathrm{L}$ of corn flour, $3 \mathrm{~g} / \mathrm{L}$ of $\mathrm{NaNO}_{3}, 4 \mathrm{~g} / \mathrm{L}$ of $\mathrm{KH}_{2} \mathrm{PO}_{4}$, and $0.01 \mathrm{~g} / \mathrm{L}$ of $\mathrm{FeSO}_{4} \cdot 7 \mathrm{H}_{2} \mathrm{O}$ The seed culture medium (initial $\mathrm{pH} 6.0$ ) was cultivated at $31^{\circ} \mathrm{C}$ and $200 \mathrm{rpm}$ for 1-2 days and then transferred into a $5 \mathrm{~L}$ fermenter (BIOFLO 3000 Batch/Continuous Bioreactor, New Brunswick Scientific Edison, NJ, USA). The submerge fermentation medium ingredients included $10 \mathrm{~g} / \mathrm{L}$ corn steep liquor, 15

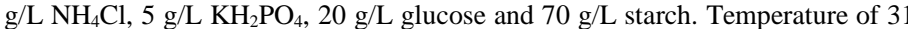
${ }^{\circ} \mathrm{C}$ and aeration of $1.5 \mathrm{~m}^{3} / \mathrm{h}$ were maintained during fermentation in fermenter. Various agitation rates from $250 \mathrm{r} / \mathrm{min}$ to $450 \mathrm{r} / \mathrm{min}$ were applied.

\section{Determination of pigments}

According to the similar method of Chinese National Standard, GB15961-2005 and some reported articles (Bo et al., 2009), absorbance was applied to represen the pigments concentration. Five $\mathrm{mL}$ of culture broth was mixed with $5 \mathrm{~mL}$ of $70 \%$ (v/v) ethanol for 1 hour, and then centrifuged at 4,000 rpm for $20 \mathrm{~min}$. The obtained supernatant was filtered through filter paper $(45 \mu \mathrm{m}$, Xinhua Paper Industry Co., Ltd, Hangzhou, China). The filtrate contained two pigments: yellow pigment and red pigment, whose concentrations were determined by measuring the optical density of the supernatant using a 2802SUV/VIS spectrophotometer (Unicosh Scientific Instrument Co., Ltd, Shanghai, China) at 410 and $510 \mathrm{~nm}$, respectively. Results were expressed as $O D$ units per $\mathrm{mL}$ of fermented broth. The linearity equation between absorbance and diluting proportions is $\mathrm{y}=$ $0.0054 \mathrm{x}+1.5462\left(\mathrm{R}^{2}=0.9907\right)$, where $\mathrm{y}$ is absorbance and $\mathrm{x}$ is dilution proportions (in the range from 100 to 300 ).

\section{Determination of Dried Cell Weight (DCW)}

Fungal biomass was determined by gravimetric analysis after filtration of cell samples through preweighed nylon filters ( $45 \mathrm{~mm}$ diameter, $0.8 \mu \mathrm{m}$ porosity) and dried to constant weight at $60{ }^{\circ} \mathrm{C}$ under partial vacuum $(200 \mathrm{~mm} \mathrm{Hg})$.

\section{Determination of Residual Sugar Concentration (RSC)}

The residual glucose in the fermentation broth was determined with a spectrophotometer by the standard 3,5-dinitrosalicylic acid (DNS) method (Miller, 1959), and the calibration curve was prepared using glucose.

\section{Determination of $\mathrm{NH}_{4}{ }^{+}$Concentration}

The Berthelot reaction (Weatherburn, 1967) was used for determination of ammonium ion.

\section{Determination of Soluble Starch Concentration}

The soluble starch was measured by the modified method of Teng (Teng and Feldheim, 2001). Briefly, sample $(0.5 \mathrm{~mL})$ was hydrolyzed by using $0.5 \mathrm{~mL}$ of thermostable $\alpha$-amylase (EC 3.2.1.1, Novo, Denmark) at $100{ }^{\circ} \mathrm{C}$ for $60 \mathrm{~min}$ and then $0.25 \mathrm{~mL}$ of amyloglucosidase (EC 3.2.1.3, Novo, Denmark) at $60{ }^{\circ} \mathrm{C}$ overnight. The amount of glucose was determined by the DNS method. The starch content was calculated as the amount of glucose $\times 0.9$ and expressed as $g / L$ (g starch content/L cultures)

\section{Imaging and Morphological Analysis}

Sample preparation was carried out following the method described by Haack et al. (Martin et al., 2006). For image analysis, $2 \mathrm{~mL}$ of the sample was taken from the culture broth, and one or two drops of lactophenol blue was added to stop growing and increase the contrast of the images. Image capture wassig accomplished on a Zeiss light microscope. The pellets were distinguished from clumps and dispersed mycelia by the differences in the greyness levels, an approach that has been used to provide a definition for a pellet (Thomas 1992). Morphological measurements were carried out using a CMOS camera (IXUS115; Canon, Japan) and the Image-Pro PLUS software (Media Cybernetics Inc., USA). The average clump diameter was calculated on images obtained using a $4 \times$ objective. Data, reported as the mean $\pm \mathrm{SD}$, were obtained from a population size of approximately 100 events per sample.

\section{Data analysis}

The specific growth rate, $\mu\left(\mathrm{h}^{-1}\right)$, was calculated following the equation $\mu=\left(\frac{1}{X}\right)\left(\frac{d X}{d t}\right)$, where $\mathrm{X}$ is the cell concentration $(\mathrm{g} / \mathrm{L})$ at time $\mathrm{t}(\mathrm{h})$. The specific production rate of yellow pigments, $q_{y}\left(O D \cdot \mathrm{g}^{-1} \cdot \mathrm{h}^{-1}\right)$, was calculated following the equation: $q_{Y}=\left(\frac{1}{X}\right)\left(\frac{d Y}{d t}\right)$, where $\mathrm{Y}$ is the yellow pigments value $(O D)$ at time $\mathrm{t}(\mathrm{h})$. All the data shown in Tables and Figures were expressed as mean of triplicates. The statistical evaluation of all data was performed by Origin 8.0

\section{RESULTS AND DISCUSSION}

Effect of agitation speed on yellow pigments production and Monascus anka mutant growth

Significant influence of agitation on monascus yellow pigments production and Monascus anka mutant growth has been noticed in this working (Figure 1). When agitation speed was $250,300,350,400$, and $450 \mathrm{r} / \mathrm{min}$, the maximum monascus yellow pigments yield was $100.04,100.12,110.23,125.85$, and $105.97 O D$ units at 144, 126, 126, 96, and 96 hour, respectively (Figure 1A). Maximum of $\boldsymbol{q}_{\boldsymbol{y}}$ was $0.1659,0.2264,0.1741,0.1792$, and $0.2177 O D \cdot \mathrm{g}^{-1} \cdot \mathrm{h}^{-1}$ at $66,54,54,42$, and 48 hour, respectively (Figure 1B). $\mu_{\max }$ was $0.026,0.047,0.034,0.078$, and $0.064 \mathrm{~h}$ ${ }^{1}$ at $18,24,18,6$, and 24 hour, respectively (Figure 1C).

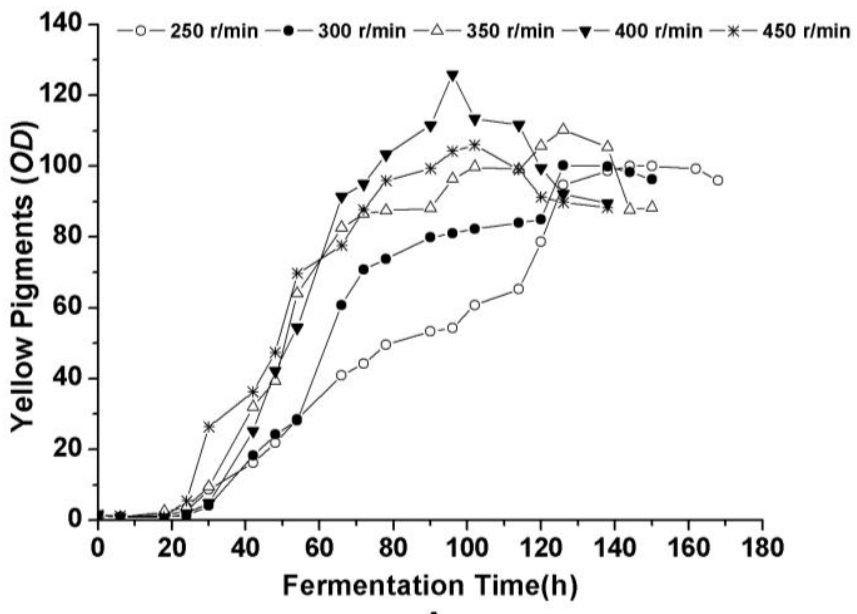

A

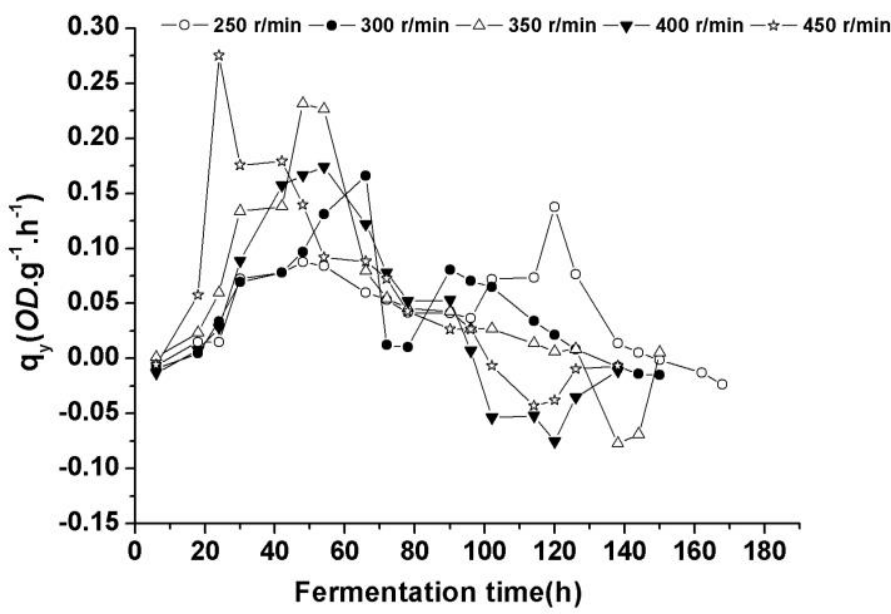

B

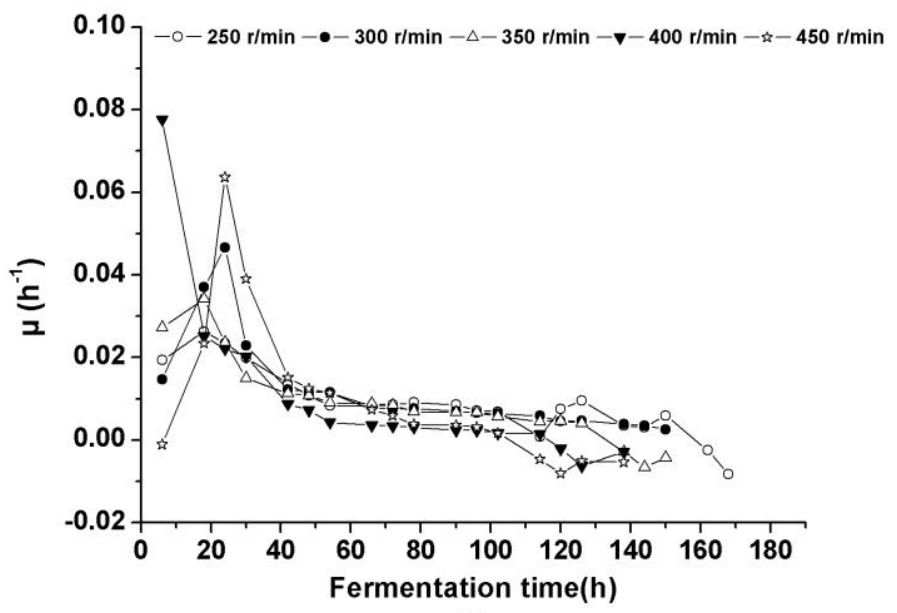

Figure 1 Effects of agitation speed on Monascus yellow pigments production (A), $\boldsymbol{q}_{\boldsymbol{y}}(\mathrm{B})$ and $\mu(\mathrm{C})$ 
These results demonstrated that time for yellow pigments production has been in advanced with high maximum specific production rate by high agitation speed, but higher agitation speed led to faster decrease of $\boldsymbol{q}_{\boldsymbol{y}}$ at fermentation anaphase. Meanwhile, high agitation speed can improve specific growth rate for Monascus anka mutant at fermentation prophase, but negative for Monascus anka mutant growth at fermentation anaphase.

\section{Effect of agitation on substrates utilization by Monascus anka mutant}

With the increase of agitation speed, the maximum residual sugar content in culture appeared at 18 hour. Thereafter, the residual sugar content showed a downward trend with increased agitation (Figure 2A). The soluble starch content almost reached stable stage at 18 hours as shown in Figure 2B. The possible reason for this phenomenon is that hydrolysis of soluble starch was faster than the consumption of glucose at the initial stage (Teng et al., 2001). Prolonged fermentation time did not digest starch very much. The soluble starch in the culture with higher agitation speed was lower at the end of the fermentation.

(Figure 2B). $\mathrm{NH}_{4}{ }^{+}$was used as nitrogen source in the present work. Sharp decrease of $\mathrm{NH}_{4}{ }^{+}$was observed in the first $48 \mathrm{~h}$ beside of culture at $250 \mathrm{r} / \mathrm{min}$ (Figure 2C)

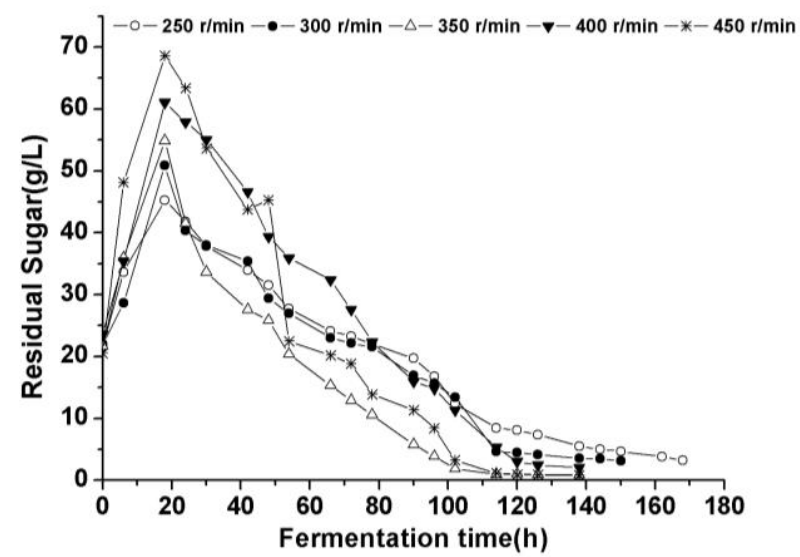

A

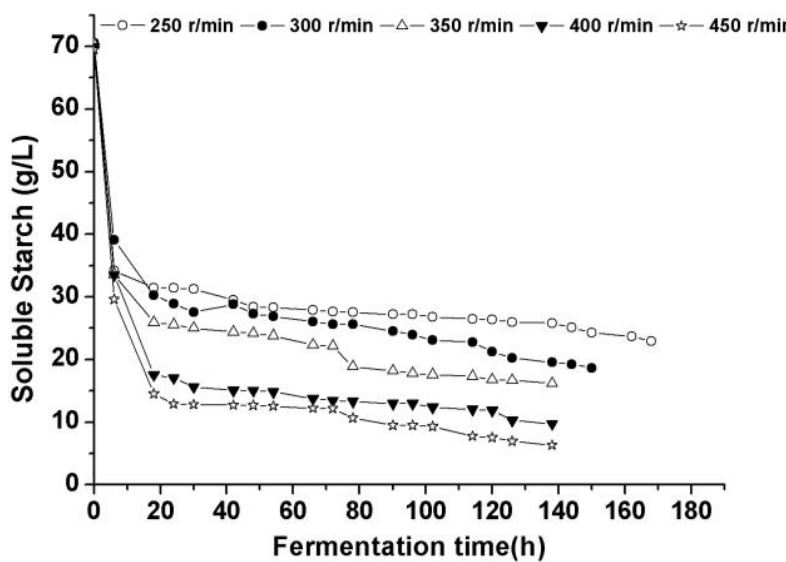

B

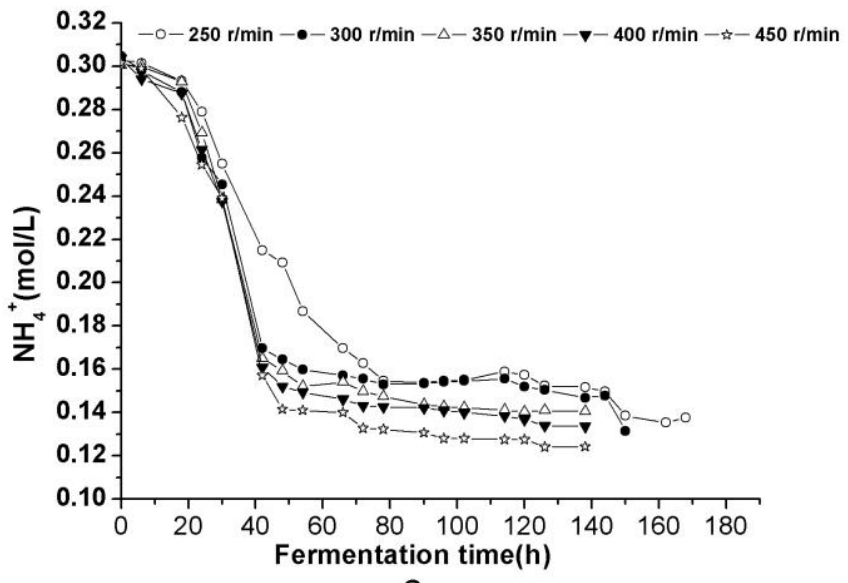

Figure 2 Effects of agitation on residual sugar (A), soluble starch (B) and $\mathrm{NH}_{4}{ }^{+}$ (C) utilization by Monascus anka mutant
The above results indicated that $400 \mathrm{r} / \mathrm{min}$ at fermentation metaphase while 300 $\mathrm{r} / \mathrm{min}$ at fermentation anaphase was beneficial for substrates utilization. In general, higher agitation speed improved the hydrolysis of soluble starch (Teng et al., 2001) and $\mathrm{NH}^{4+}$ consumption (Bo et al., 2014). From Figure $1 \mathrm{~A}$, it seemed that residual glucose in fermentation broth with agitation speed of $450 \mathrm{r} / \mathrm{min}$ was higher than that with the speed of $350 \mathrm{r} / \mathrm{min}$. However, it should be noted that the residual soluble starch in fermentation broth with agitation speed of $250 \mathrm{r} / \mathrm{min}$ was much higher than that of the fermentation with the speed of $450 \mathrm{r} / \mathrm{min}$. Therefore, fermentation with higher agitation speed metabolized more glucose.

Effect of agitation-shift on yellow pigments production by Monascus anka mutant

From the above experimental results concerning different agitation speed on the yellow pigments production by Monascus anka mutant, stage-divided strategy may improve yellow pigments production and enhance Monascus anka mutan growth with efficient utilization of substrate theoretically. The stage-divided strategy was as follows: $400 \mathrm{r} / \mathrm{min}$ was carried out to improve the Monascus mutant growth and yellow pigments production before fermentation of 96 hour and then $300 \mathrm{r} / \mathrm{min}$ was applied to increase yellow pigment production with efficient substrate conversion.

Under agitation-shift strategy in batch monascus yellow pigments fermentation, the maximum yellow pigments yield reached $149.43 \mathrm{OD}$ at 102 hour, which was $49.37 \%, 49.25 \%, 35.56 \%, 18.73 \%$, and $41.01 \%$ higher than that of $250,300,350,400$, and $450 \mathrm{r} / \mathrm{min}$, respectively (Figure. 3A). Maximum $\boldsymbol{q}_{y}$ and $\mu_{\max }, 0.2177 O D \cdot \mathrm{g}^{-1} \cdot \mathrm{h}^{-1}$ and $0.0528 \mathrm{~h}^{-1}$, respectively, was achieved at fermentation time of 48 hours and 6 hours (Figure 3B). $\boldsymbol{\mu}$ and $\boldsymbol{q}_{\boldsymbol{y}}$ could be maintained at $0.01 \mathrm{~h}$ ${ }^{1}$ and $0.1 O D \cdot \mathrm{g}^{-1} \cdot \mathrm{h}^{-1}$ from 6 hours to 54 hours and 24 hours to 66 hours respectively. It was impossible to achieve using single temperature-shift strategy (Figure 3B). It showed that the yield of yellow pigments was higher than those of reports (Shi et al., 2015; Klinsupa et al., 2016; Krairak et al., 2000; Bo et al., 2009; Hu et al., 2012; Tao et al., 2017).
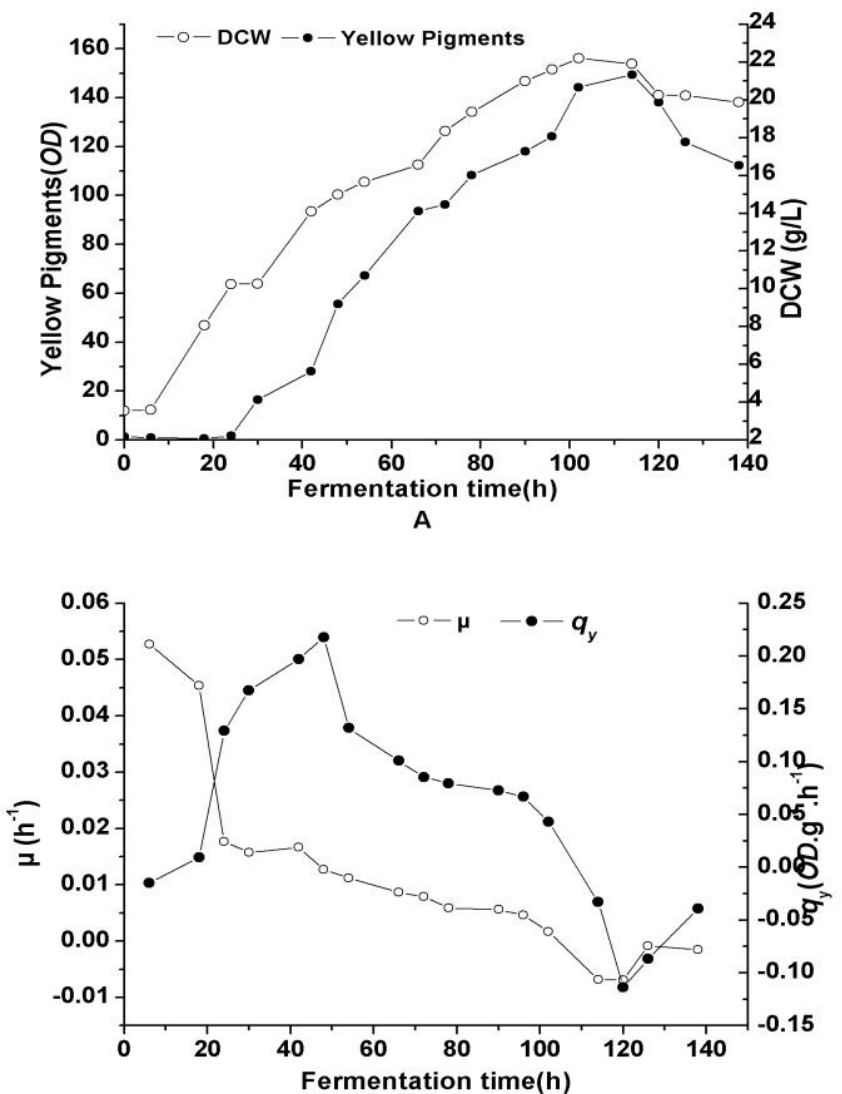

Figure 3 Effects of two stage agitation control on Monascus yellow pigment production (A) and Monascus anka mutant growth (B)

Under two stage agitation control, soluble starch was 19.79 and $10.37 \mathrm{~g} / \mathrm{L}$ at 18 and 96hour, respectively. In the first $18 \mathrm{~h}$, the content of soluble starch was decreased significantly. Meanwhile, reducing sugar content showed the highest at $8 \mathrm{~h}$. The reducing sugar content, soluble starch content and $\mathrm{NH}_{4}{ }^{+}$content was $8.24 \mathrm{~g} / \mathrm{L}, 7.37 \mathrm{~g} / \mathrm{L}$ and $0.135 \mathrm{~mol} / \mathrm{L}$, respectively at the end of fermentation. The yield of amylase produced by Monascus, which can hydrolyze soluble starch into sugar (Teng et al., 2001), could be increased by the higher agitation speed and therefor the reducing sugar utilization was accelerated. Higher agitation speed significantly enhanced the carbon source (reducing sugar and soluble starch) 
consumption by Monascus anka mutant (Figure.2). However, $\mathrm{NH}_{4}{ }^{+}$may be only used for Monascus anka mutant growth because agitation has no obviously influence on change of $\mathrm{NH}_{4}{ }^{+}$contents in post-fermentation but only in early fermentation in culture (Figure1-2). All the above results indicated two stage agitation control could obviously improve substrate metabolism (Figure 4), the yield of product relative to soluble starch and $\mathrm{NH}_{4}{ }^{+}$, and accelerate the Monascus growth and yellow pigments production, leading to a short fermentation time eventually (Table 1) compared with one-stage agitation strategy.

Table 1 Important parameters of yellow pigments production under different agitation condition

\begin{tabular}{|c|c|c|c|c|c|}
\hline agitation (r/min) & Maxium $\mu\left(h^{-1}\right)$ & $\begin{array}{l}\operatorname{Maxium} q_{Y} \\
\left(O D \cdot \mathrm{g}^{-1} \cdot \mathrm{h}^{-1}\right)\end{array}$ & $\begin{array}{l}\text { yield of yellow pigments } \\
\text { relative to ammonium ion( } O D \\
\left.. \mathrm{mol}^{-1}\right)\end{array}$ & $\begin{array}{l}\text { yield of yellow pigments } \\
\text { relative to } \operatorname{starch}\left(O D \cdot \mathrm{g}^{-1}\right)\end{array}$ & $\begin{array}{l}\text { Culture colour } \\
\text { change(h) }\end{array}$ \\
\hline 250 & $0.026(18 \mathrm{hr})$ & $0.0877(48 \mathrm{hr})$ & 652193.8 & 2202.67 & 23 \\
\hline 300 & $0.047(24 \mathrm{hr})$ & $0.1659(66 \mathrm{hr})$ & 649244.5 & 1990.17 & 22 \\
\hline 350 & $0.034(18 \mathrm{hr})$ & $0.2264(54 \mathrm{hr})$ & 691400.6 & 2051.62 & 21 \\
\hline 400 & $0.078(6 \mathrm{hr})$ & $0.1741(54 \mathrm{hr})$ & 774223.3 & 2211.38 & 21 \\
\hline 450 & $0.064(24 \mathrm{hr})$ & $0.1792(42 \mathrm{hr})$ & 610813.3 & 1760.16 & 15 \\
\hline Two-stage & $0.053(6 \mathrm{hr})$ & $0.2177(48 \mathrm{hr})$ & 915568.9 & 2458.67 & 20 \\
\hline
\end{tabular}

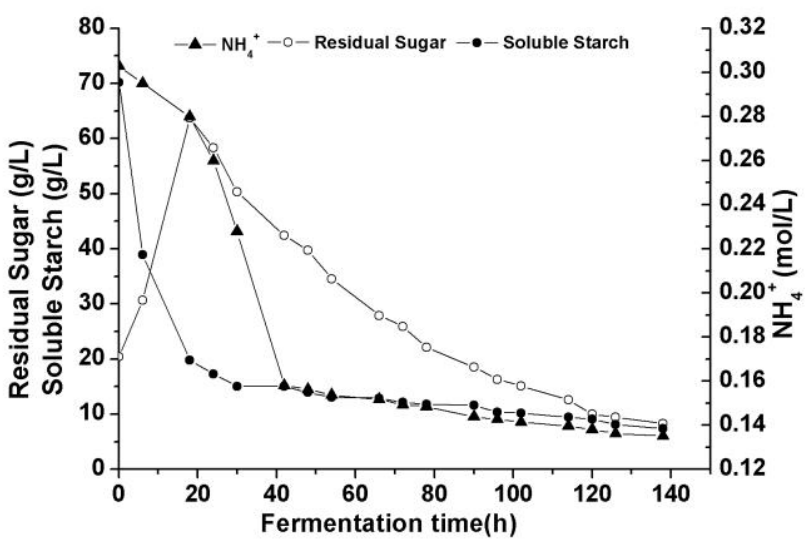

Figure 4 Effect of two stage agitation control on substrate utilization by Monascus anka mutant

\section{Effect of agitation on morphological changes of Monascus anka mutant}

Compared with single cell microorganism, there is morphological changes in filamentous fungi lifecycle by liquid and solid fermentation, especially more obvious and complex for submerge culture, then the morphological changes lead to influence on the target metabolites production. Three morphologies of filamentous fungi, such as free filaments, clump and pellet, appear in liquid culture (Thomas 1992). There are two reasons of morphological changes to influence metabolite: 1) secretion mechanisms changes, 2) rheological properties changes of culture, including oxygen mass transfer (Wucherpfennig et al. 2010). Besides incubation, $\mathrm{pH}$, metal, substrate, temperature and oxygen, the agitation is the major factor on morphological changes (Kaup et al., 2008; Krull et al., 2010).

The mycelia morphology appeared free filaments and clump when agitation was $250 \mathrm{r} / \mathrm{min}$ and $300 \mathrm{r} / \mathrm{min}$, respectively. Mycelia morphology was between free pellet and clump under $350 \mathrm{r} / \mathrm{min}$. Mycelia morphology appeared well-distributed pellet with $0.52 \mathrm{~mm}$ in diameter when agitation was $400 \mathrm{r} / \mathrm{min}$. But pellet was not well-distributed with diameter of $0.57 \mathrm{~mm}$ and some filaments appear in culture because of high agitation for $450 \mathrm{r} / \mathrm{min}$. Mycelia morphology appeared to be pellet with diameter of $0.41 \mathrm{~mm}$ and yield of yellow pigments arrived 149.43 $O D$, which was $49.37 \%$ and $18.74 \%$ higher than that from $250 \mathrm{r} / \mathrm{min}$ and 400 $\mathrm{r} / \mathrm{min}$, respectively (Table 2). In the meantime, we also found seed age for incubation had an influence on mycelia morphology in this study, when old seed (beginning synthesis yellow pigments) was inoculated into fermenter, the mycelia morphology appeared between free filaments and pellet, or clump with low yellow pigments production. However, when inoculated with fresh seed, mycelia morphology appeared to be pellet with high yellow pigments production (data not shown). The mycelial morphology of Monascus, including the pellet size and hyphal diameter, was significantly influenced by the culture conditions such as the initial $\mathrm{pH}$ and shaking speed, which further exerted great impact on the production of yellow pigments. The relationship between the agitation and the fungal morphology has also been revealed in this study for enhanced production of natural yellow pigments (Jun et al., 2017). All result demonstrated pellet of mycelia morphology was benefit for monascus yellow pigments production.

Meantimes, the citrinin was unable to be detected by HPLC method (Bo et al., 2009) in this study namely, the Monascus anka mutant may produce no or just a little citrinin (the detection limit is $0.1 \mathrm{mg} / \mathrm{L}$ )

Table 2 Effect of agitation on the mycelia morphology and yellow pigments production

\begin{tabular}{cccc}
\hline $\begin{array}{c}\text { Agitation } \\
(\mathrm{r} / \mathrm{min})\end{array}$ & $\begin{array}{c}\text { Mycelia } \\
\text { Morphology }\end{array}$ & $\begin{array}{c}\text { Mycelia } \\
\text { diameter } \\
(\mathrm{mm})\end{array}$ & $\begin{array}{c}\text { Yellow pigments } \\
(O D)\end{array}$ \\
\hline 250 & Free filaments & $1.39 \pm 0.07^{\mathrm{a}}$ & $100.04 \pm 8.76 \mathrm{c}$ \\
300 & $\begin{array}{c}\text { Free filaments } \\
\text { and clump }\end{array}$ & $0.98 \pm 0.03^{\mathrm{b}}$ & $100.12 \pm 9.54 \mathrm{c}$ \\
& Clump and pellet & $0.69 \pm 0.05^{\mathrm{c}}$ & $110.23 \pm 9.8^{\mathrm{b}}$ \\
400 & pellet \\
450 & $\begin{array}{c}\text { Pellet and Free } \\
\text { filaments } \\
\text { pellet }\end{array}$ & $0.52 \pm 0.06^{\mathrm{c}}$ & $125.85 \pm 10.73^{\mathrm{b}}$ \\
Two-stage & $0.41 \pm 0.03^{\mathrm{c}}$ & $105.97 \pm 8.79^{\mathrm{c}}$ \\
\hline $\begin{array}{l}\text { Different letters in superscript within the same row indicate significant differences among the } \\
\text { oil sample test (Tukey's test, } \mathrm{p}<0.05) .\end{array}$ &
\end{tabular}

Previously, the yield of Monascus yellow pigment could be improved by controlling pH and nitrogen sources (Shi et al., 2015) or a novel approach of twostage microbial fermentation in nonionic surfactant micelle aqueous solution (Hu et al., 2012). However, due to its $\mathrm{pH}$-dependent property, relatively low production and purity, it is impossible to scale-up yellow pigment production and application for all kinds of foods. The Monascus genus, which can produce yellow pigments owning $\mathrm{pH}$-dependent property with high yield, is the key factor, such as Monascusr mutant strain KB (Yongsmith et al., 1993; 1994) and our specific strain of Monascus anka mutant (Bo et al., 2009; 2012; 2014). In the current study, Monascus growth and yellow pigments production with high speed and longtime could be achieved by two stage agitation control strategy and short fermentation time to improve the yield of yellow pigments, which can make it possible to scale-up yellow pigment production.

\section{CONCLUSION}

To our knowledge, this is the first report focusing on the agitation optimization of Monascus yellow pigments production in submerge culture in fermenter as a source of natural yellow pigments. In the current study, Monascus anka mutant, which could produce yellow pigments with $\mathrm{pH}$-independent property (Bo et al., 2009; 2012; 2014), was cultured in a fermenter using two-stage agitation controlling strategy. Maximum yellow pigments of more than $149.43 O D$ were found in submerge culture under optimal agitation conditions: the agitation was $400 \mathrm{r} / \mathrm{min}$ to improve the Monascus growth and yellow pigments production before culture 96 hour and then $300 \mathrm{r} / \mathrm{min}$ was carried out to continue yellow pigment production with efficient substrate utilization. Future development on yellow pigments should focus on strain improvement for higher production of yellow pigments as well as process scaling up. Hopefully, the results in this paper have very important theoretical and realistic significance for realizing the industrial production of monascus yellow pigments by submerged culture. The data of this work could contribute to making the industrial production of Monascus yellow pigments feasible.

Acknowledgments: This research work was financially supported by the National Natural Science Foundation of China (Nos.31301550), scientific research project of Hunan province department of education (Nos. 14C1185), Program for Science \& Technology Innovation Talents of Hunan Province (2017TP1021; KC1704007).

\section{REFERENCE}

Blanc, P.J., Loret, M.O., Santerre, A.L. 1994. Pigments of Monascus. Journal of Food Science, 59(4), 862-865. $\quad$ http://dx.doi.org/10.1111/j.13652621.1994.tb08145.x

Bo, Z., Jingjing, K. 2012. A Temperature-Shift Strategy in Batch Monascus Yellow Pigments Fermentation. Advanced Materials Research, 550-553, 13271335. https:// dx.doi.org/10.4028/www.scientific.net/AMR.550-553.1327 
Bo, Z., Jufang, W., Yuewu, P., Mingjun, Z., Siming, L., Shizhong, L. 2009. Optimization of culture medium for yellow pigments production with Monascus anka using response surface methodology. European Food Research and Technology, 228(6), 895-901. https:// dx.doi.org/10.1007/s00217-008-1002-Z Bo, Z., Yan, W., Huamin, L., Yanqing, Z. 2014. Effect of Ammonium Salts on Pigments Production by Monascus anka Mutant in 5L Bioreactor. Chiang Mai Journal of Science, 41(5.1), 1032-1043.

Chen, G., Shi, K., Song, D., Quan, L., Wu, Z. 2015. The pigment characteristics and productivity shifting in high cell density culture of Monascus anka mycelia. BMC Biotechnology, 15, 72. https:// dx.doi.org/10.1186/s12896-015-0183-3

Feng, Y.L., Shao, Y.C., Chen, F.S. 2012. Monascus pigments. Applied $\begin{array}{llll}\text { Microbiology and } \quad \text { Biotechnology, 96(6), 1421-1440. } & \end{array}$ https://dx.doi.org/10.1007/s00253-012-4504-3

Gomes, D.C., Takahashi, J.A. 2016. Sequential fungal fermentation biotransformation process to produce a red pigment from sclerotiorin. Food Chemistry, 210, 355-361. https:// dx.doi.org/10.1016/j.foodchem.2016.04.057 Gong, C., Zhenqiang, W. 2016. Production and biological activities of yellow pigments from Monascus fungi. World Journal of Microbiology and Biotechnology, 32(8), 136. https:// dx.doi.org/ 10.1007/s11274-016-2082-8

Hsu, Y., Lee, B., Liao, T. 2012. Monascus fermented metabolite monascin suppresses inflammation via PPAR- $\gamma$ regulation and JNK inactivation in THP-1 monocytes. Food and Chemical Toxicology, 50(5), 1178-1186 https://dx.doi.org/10.1016/j.fct.2012.02.029

Hsu, W.H., Chen, T.H., Lee, B.H., Hsu, Y.W., Pan, T.M. 2014. Monascin and ankaflavin act as natural AMPK activators with PPARa agonist activity to downregulate nonalcoholic steatohepatitis in high-fat diet-fed C57BL/6 mice. Food and Chemical Toxicology, 64, 94-103._https:// dx.doi.org/10.1016/j.fct.2013.11.015

Hu, Z.Q., Zhang, X.H., Wu, Z.Q., Qi, H.S., Wang, Z.L. 2012. Export of intracellular Monascus pigments by two-stage microbial fermentation in nonionic surfactant micelle aqueous solution. Journal of Biotechnology, 162(2-3), 202 209. https://dx.doi.org/10.1016/j.jbiotec.2012.10.004

Hyun, J.K., Jong, H.K., Hyuck, J.O., Chul, S.S. 2002. Morphology control of Monascus cells and scale-up of pigment fermentation. Process Biochemistry 38(5), 649-655. https:// dx.doi.org/10.1016/S0032-9592(02)00095-X

Jun, L., Bo-Bo, Z., Xiao-Dong, L., Chan, Z., Lei, C., Gan-Rong, X., Peter Chi Keung, C. 2017. Enhanced production of natural yellow pigments from Monascus purpureus by liquid culture: The relationship between fermentation conditions and mycelial morphology. Journal of Bioscience and Bioengineering, 124(4), 452-458. https://dx.doi.org/10.1016/j.jbiosc.2017.05.010

Kaup, B.A., Ehrich, K., Pescheck, M., Schrader, J. 2008. Microparticle-enhanced cultivation of filamentous microorganisms:increased chloroperoxidase formation by Caldariomyces fumago as an example. Biotechnology and Bioengineering, 99(3), 491-498. http://dx.doi.org/10.1002/bit.21713

Klinsupa, W., Phansiri, S., Thongpradis, P., Thongpradis, P., Yongsmith, B., Pothiratana, C. 2016. Enhancement of yellow pigment production by intraspecific protoplast fusion of Monascus spp. yellow mutant (ade-) and white mutant (prototroph). Journal of Biotechnology, 217, 62 71.https://dx.doi.org/10.1016/j.jbiotec.2015.11.002

Krairak, S., Yamamura, K., Irie. R., Nakajima, M., Shimizu, H., Chim-Anage, P., Yongsmith, B., Shioya, S. 2000. Maximizing yellow pigment production in fedbatch culture of Monascus sp. Journal of Bioscience and Bioengeering, 90(4), 363-367.https://dx.doi.org/10.1016/S1389-1723(01)80002-5

Krull, R., Cordes, C., Horn, H., Kampen, I., Kwade, A., Neu, T. 2010 Morphology of filamentous fungi: linking cellular biology to process engineering using Aspergillus niger. Advances in Biochemical Engineering/Biotechnology, 121, 1-21. http://dx.doi.org /10.1007/10_2009_60

Lee, C., Kung, Y., Wu, C., Hsu, Y., Pan, T. 2010. Monascin and ankaflavin act as novel hypolipidemic and high-density lipoprotein cholesterol-raising agents in red mold Dioscorea. Journal of Agriculture and Food Chemistry, 58(16), 9013 9019. https://dx.doi.org/10.1021/jf101982v

Lee, C., Wen, J., Hsu, Y. 2013. Monascus-fermented yellow pigments monascin and ankaflavin showed antiobesity effect via the suppression of differentiation and lipogenesis in obese rats fed a high-fat diet. Journal of Agriculture and Food Chemistry 61(7), 1493-1500. https:// dx.doi.org/10.1021/if304015z

Lin, T.F., Yakushijin, K., Buchi, G.H., Demain, A.L. 1992. Formation of watersoluble Monascus red pigments by biological and semi-synthetic processes. Journal of Industrial Microbiology, 9(3-4), 173-179. https://dx.doi.org/10.1007/BF01569621

Ma, J., Li, Y., Ye, Q., Li, J., Hua, Y., Ju, D., Zhang, D., Cooper, R., Chang, M 2000. Constituents of red yeast rice, a traditional Chinese food and medicine. Journal of Agriculture and Food Chemistry, 48(11), 5220-5225. http://dx.doi.org/10.1021/jf000338c

Martin, B.H., Lisbeth, O., Kim, H., Anna, E.L. 2006. Change in hypha morphology of Aspergillus oryzae during fed-batch cultivation. Applied $\begin{array}{llll}\text { Microbiology and } \quad \text { Biotechnology, } & \text { 70(4), }\end{array}$ https://dx.doi.org/10.1007/s00253-005-0085-8

Mapari, S.A.S., Meyer, A.S., Thrane, U. 2009a. Photostability of natural orangered and yellow fungal pigments in liquid food model systems. Journal of
Agricultural and Food Chemistry, 57(14),

$6253-6261$ https://dx.doi.org/10.1021/if900113q

Mapari, S.A.S, Meyer, A.S., Thrane, U., Frisvad, J.C. 2009b. Identification of potentially safe promising fungal cell factories for the production of polyketide natural food colorants using chemotaxonomic rationale. Microbial Cell Factories, 8, 1-15. https://dx.doi.org/10.1186/1475-2859-8-24

Mapari, S.A.S., Thrane, U., Meyer, A.S. 2010. Fungal polyketide azaphilone pigments as future natural food colorants. Trends Biotechnology, 28(6), 300-307. https:// dx.doi.org/10.1016/j.tibtech.2010.03.004

Miller, G.L. 1959. Use of dinitrosalicylic acid reagent for determination of reducing sugar. Analyticaal Chemistry, 31(3), 426-428 https://dx.doi.org/10.1021/ac60147a030

Shi, Y., Liao, V.H., Pan, T. 2012. Monascin from red mold dioscorea as a novel antidiabetic and antioxidative stress agent in rats. Free Radical Biology and Medicine, $52(1)$

dx.doi.org/10.1016/j.freeradbiomed.2011.09.034

Shi, K., Song, D., Chen, G., Pestalozzi, M., Wu, Z.Q., Quan, L. 2015. Controlling composition and color characteristics of Monascus pigments by $\mathrm{pH}$ and nitrogen sources in submerged fermentation. Journal of Bioscience and Bioengineering, 120(2), 145-154. https:// dx.doi.org/10.1016/i.jbiosc.2015.01.001

Su, N., Lin, Y., Lee, M., Ho, C. 2005. Ankaflavin from Monascus-Fermented red rice exhibits selective cytotoxic effect and induces cell death on Hep G2 cells. Journal of Agriculture and Food Chemistry, 53(6), 1949-1954. https://dx.doi.org/10.1021/jf048310e

Tao, H., Meihua, W., Kan, S., Gong, C., Xiaofei, T., Zhenqiang, W. 2017. Metabolism and secretion of yellow pigment under high glucose stress with Monascus ruber._AMB Express, 7, 79. https:// dx.doi.org/ 10.1186/s13568-017$\underline{0382-5}$

Teng, S.S., Feldheim, W. 2001. Anka and anka pigment production. Journal of industrial microbiology \& biotechnology, 26(5), 280-282. https://dx.doi.org/ 10.1038/sj.jim.7000126

Thomas, C.R. 1992. Image analysis: putting filamentous microorganisms in the picture. Trends in Biotechnology, 10(11), 343-348. http://dx.doi.org/10.1016/0167-7799(92)90266-X

Upadhyaya, L., Singh, J., Agarwal, V., Pandey, A.C., Verma, S.P., Das, P., Tewari, R.P. 2015. Efficient water soluble nanostructured $\mathrm{ZnO}$ grafted Ocarboxymethyl chitosan/curcumin-nanocomposite for cancer therapy. Process Biochemistry, 50(4), 678-688.https:// dx.doi.org/10.1016/j.procbio.2014.12.029

Vendruscolo, F., Bühler, R.M.M., Carvalho, J.C.d., Oliveira, D.D., Moritz, D.E. Schmidell, W., Ninow, J.L. 2016. Monascus: a reality on the production and application of microbial pigments. Applied Biochemistry and Biotechnology, 178, 211-223. https://dx.doi.org/10.1007/s12010-015-1880-z

Wang, T.H., Lin, T.F. 2007. Monascus rice products. Advances in Food and Nutrition Research, 53,123-159. http://dx.doi.org/ 10.1016/S10434526(07)53004-4

Weatherburn, M.W. 1967. Approach for Phenol-Hypochlorite Reaction for Determination of Ammonia. Analytical Chemistry, 39 (8), 971-974. http://dx.doi.org/10.1038/sj.jim.7000126 10.1021/ac60252a045

Wild, D., Toth, G., Humpf, H.U. 2000. New Monascus metabolite isolated from red yeast rice. Journal of Agriculture and Food Chemistry, 50(14), 3999-4002. http://dx. doi.org/10.1021/jf020023s

Wucherpfennig, T., Hestler, T., Krull, R. 2011. Morphology engineering osmolality and its effect on Aspergillus niger morphology and productivity. Microbial Cell Factories, 10, 58. http://dx. doi.org /10.1186/1475-2859-10-58 Wucherpfennig, T., Kiep, K.A., Driouch, H., Wittmann, C., Krull, R. 2010 Morphology and rheology in filamentous cultivations. Advances in Applied Microbiology, 72, 89-136. http://dx. doi.org/10.1016/S0065-2164 (10)72004-9

Xiong, X., Zhang, X.H., W, Z.Q., Wang, Z.L. 2015. Coupled aminophilic reaction and directed metabolic channeling to red Monascus pigments by extractive fermentation in nonionic surfactant micelle aqueous solution. Process Biochemistry, 50(2), 180-187. https://dx. doi.org/10.1016/j.procbio.2014.12.002 Xu, H., Yang, X.P., Li, G., Zhao, C., Liao, X.J. 2015. Green synthesis of fluorescent carbon dots for selective detection of tartrazine in food samples. Journal of Agricultural and Food Chemistry, 63(30), 6707-6714 https://dx.doi.org/10.1021/acs.jafc.5b02319

Xu, X., Jin, W.Y., Jiang, L., Xu, Q., Li, S., Zhang, Z.D., Huang, H. 2016. A hight-hrough put screening method for identifying lycopene-overproducing $E$. coli strain based on an antioxidant capacity assay. Biochemical Engineering Journal, 112, 277-284.https://dx. doi.org/10.1016/j.bej.2016.04.032

Yongsmith, B., Krairak, S., Bavavoda, R. 1994. Production of yellow pigment in submerged culture of a mutant of Monascus sp.. Journal of Fermentation and Bioengineering, 78,223-228. https://dx. doi.org/10.1016/0922-338X(94)90294-1

Yongsmith, B., Tabloka, W., Yongmanitchai, W., Bavavoda, R. 1993. Culture conditions for yellow pigment formation by Monascus sp. KB10 grown on cassava medium. World Journal of Microbiology and Biotechnology, 9(1), 8590. http://dx.doi.org/10.1007/BF00656524

Zhang, S.H., Shi, Z., Wang, J.S. 2015. Sensitive and rapid determination of quinoline yellow in drinks using polyvinylpyrrolidone-modified electrode. Food Chemistry, 173, 449-453. https://dx. doi.org/10.1016/i.foodchem.2014.10.050 